\title{
Autologous stem cell therapy to treat chronic ulcer in heifer- A case study
}

\author{
Jayakrushna Das¹, Indramani Nath¹, Rabindra Kumar Das², Padmanav Routray³, Sidhartha Sankar Behera ${ }^{1}$ \\ 1. Department of Veterinary Surgery and Radiology, College of Veterinary Science and Animal Husbandry, \\ Orissan University of Agriculture and Technology, Bhubaneswar-751 003, Odisha, India; 2. Department of \\ Veterinary Anatomy, College of Veterinary Science and Animal Husbandry, Orissan University of Agriculture \\ and Technology, Bhubaneswar-751 003, Odisha, India; 3. Central Institute of Freshwater Aquaculture, \\ Kausalyaganga, Bhubaneswar, Orissa, India.
}

Corresponding author: Jayakrushna Das, E-mail: drjohndasjajpur@yahoo.co.in

Received: 13-09-2012, Accepted: 05-10-2012, Published online: 19-11-2012 doi: $10.5455 /$ vetworld.2012.771-774

\begin{abstract}
Aim: The study was conducted to reveal the efficacy of Bone marrow derived mesenchymal stem cells (BM-MSCs) based therapy in healing of chronic non-healing and ulcerative wound in bovine species.

Materials and Methods: One 2 years old Jersey heifer affected with chronic ulcerative wound involving full thickness skin and under lying muscle at dorsal side of lumbar region since four months at the time of presentation. Bone marrow was collected from tibia, cultured and grown and after achievement of optimum confluence it was applied at the site. Different parameters of clinical, physiological, haematological, biochemical, histochemical, histological, tensile strength and photographic evaluations were done during the study period.

Results: The estimated values of above mentioned parameters on zero day and after healing (18 days) showed significant difference $(\mathrm{P} \leq 0.05)$ in relation to collagen content, tensile strength and physical characteristics of wound like extent of wound, size of wound, type of exudates and photography. But clinical, haematological and biochemical data showed no significant difference.

Conclusion: The BM-MSCs were the main pioneers to bring the chronic ulcerative wound towards healing. The procedure is simple, safe and effective in bringing out healing without showing any adverse effect on host.

Key words: BM-MSCs, bovine, chronic ulcerative wound
\end{abstract}

\section{To cite thisarticle:}

Das J, Nath I, Das RK, Routray P, Behera SS (2012) Autologous stem cell therapy to treat chronic ulcer in heiferA case study, Vet World, 5(12): 771-774, doi: 10.5455/vetworld.2012.771-774

\section{I ntroduction}

Chronic non-healing or slow healing ulcers represent a major health burden and continue to pose a challenge not only to the patient owners but to the treating physician and medical procedures as a whole. The healing of wound occurs by primary intention and secondary intention $[1,2,3]$. The therapeutic application of autologous BM derived MSCs (Bone marrow derived mesenchymal stem cells) have revolutionized the field of regenerative medicine. The BM-MSCs were been used for the treatment of chronic wound in diabetic patients [4], for non-healing ulcers of lower extremities in human being [5], cutaneous radiation syndrome in minipig model [6] and in dogs [7] proved successful in their findings. A clinical case of 2 years old Jersey heifer was presented with one large size chronic non-healing wound at lumbar region since 4 months. It was treated with different standard therapeutic regimens since then but showing no tendency towards healing. Hence one clinical trial was made with autologous bone marrow derived stem cell (BMMSCs) therapy and to know the progress and duration of healing with this application.

\section{Materials and Methods}

The owner was fully informed and written consent was obtained about the clinical trial, risk and benefits of the proposed cell based therapy. It was also approved by the Institutional Animal Ethics Committee of the institution since it was a clinical case and related to Agricultural Production Research. Measurement of the wound dimension was taken along with swab from wound bed for bacteriological culture and sensitive test (Fig.1). Biopsy was done from wound bed for histopathological and histochemical study. Wound was washed, cleaned and dressed with fly repellent spray. Under peroneal nerve block and local infiltration with $2 \%$ lignocaine hydrochloride, the proposed site i.e antero-medial 

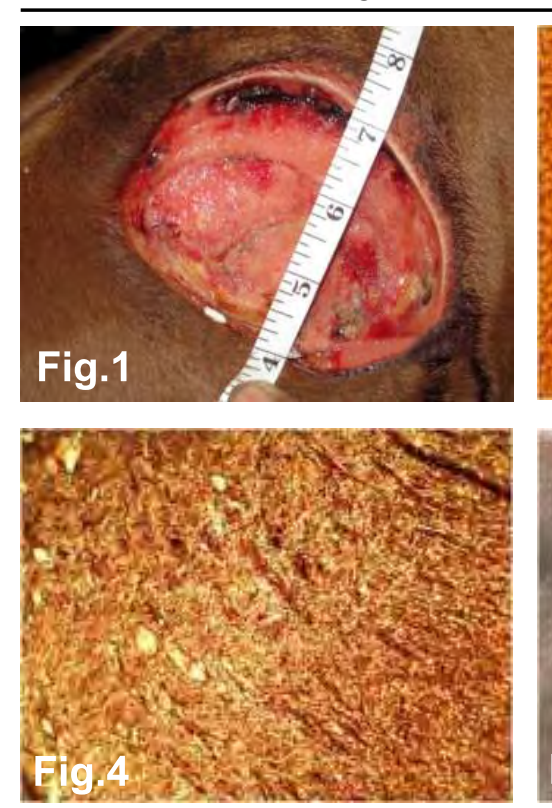
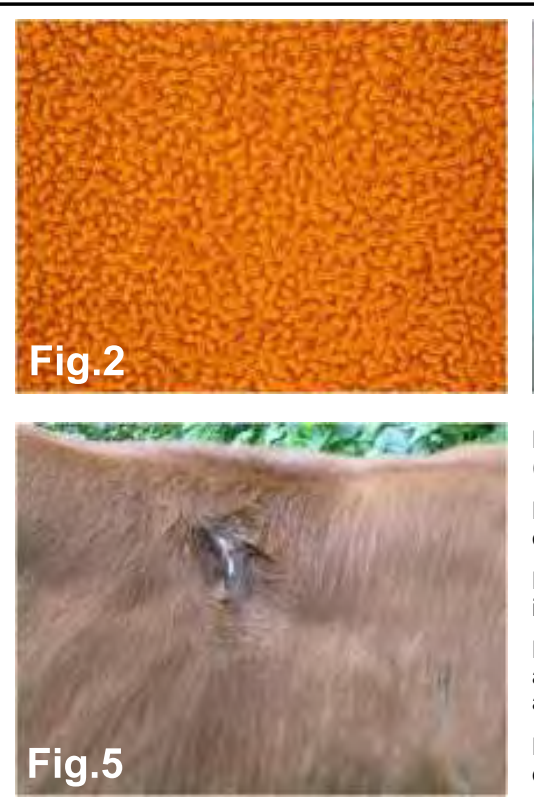

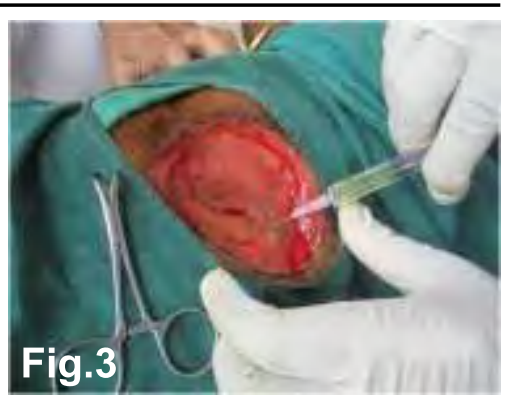

Fig-1. Measurement of wound dimension (length)

Fig-2. Photomicrograph of cultured BM cells on day-5. $40 \mathrm{X}$

Fig-3. Application of BM-MSCs by intradermal injection

Fig-4. Formation of granulation tissue and abundant neovascularisation after BM-MSCs application

Fig-5. Photograph showing healing after 18 days of BM-MSCs application aspect of tibia was prepared aseptically for bone marrow collection. A $0.5 \mathrm{~cm}$ long incision was made and tibia was drilled with $2 \mathrm{~mm}$ drill bit. $10 \mathrm{ml}$ of bone marrow was aspirated in a sterile syringe primed with EDTA (Himedia) @ 1mg/ml. The EDTA mixed bone marrow was despatched keeping inside ice packed thermo cool to the stem cell laboratory for culture and growth.

Conditioned media was prepared for culture with commercially available basic ingredients as per Table-1. The medium was changed reguraly and cell morphology was examined under a Nikon phase contrast microscope. After complete colony formation the cultured MSCs were taken for therapeutic application (Fig.2). As the stem cell therapy requires complete sterile medium, the ulcerated wound site was prepared aseptically. The prepared BM-MSCs was diluted with normal saline solution (NSS) at 2: 1 ratio and implanted intra-dermally and topically on wound bed (Fig.3) and then bandaged with paraffin wet bandage. Outwardly fly repellent spray was sprinkled. The clinical parameters like rectal temperature $\left({ }^{0} \mathrm{C}\right)$, pulse rate (beats/min), respiration rate (breaths/min) and status of visible mucous membrane were recorded on the day of presentation, BM collection, BM-MSCs implantation and $18^{\text {th }}$ days after healing. The photographic evaluation along with dimension of the ulcerative wound was measured during healing period. Haematological and biochemical parameters were estimated during the study (Table-2). Histopathology with $\mathrm{H}$ and $\mathrm{E}$ stain and Masson-Trichrome stain for study of collagen content were carried out.
Quantitative estimation of collagen content of tissue was also done with Sircol $^{\mathrm{TM}}$ method by help of spectrophotometer at $555 \mathrm{~nm}$ wave length $[8,9]$. The study of tensile strength and strain of tissue was carried out after 60 days of healing and compared with normal skin by help of Universal testing machine (Instron 3382, USA) with running rate $50 \mathrm{~mm} /$ minute at $27^{\circ} \mathrm{C}$ temperature and $65 \%$ humidity.

\section{Results and Discussion}

During the study period the physiological, haematological and biochemical parameters through varied but remained within the normal physiological range. On the basis of culture and sensitivity test antibiotic inj. Ciprofloxacine @ $5 \mathrm{mg} / \mathrm{kg}$ body weight was administered parentrally for 5 days. Regarding collection of bone marrow it was collected from femur and tibia of rats [10], mouse [11], mongrel dogs [12], iliac crest of femur [7], humerus in minipigs [6]. In this study the bone marrow was collected from proximal antero-medial aspect of tibia owing to its superficial in position, very thin layer of tissue over the bone and easy for collection. Histopathology after therapy showed neovascularization with appearance of fibroblasts, sebaceous glands and epithelialisation which supports the progression of healing process (Fig.4).

Histo-chemical study showed formation of more collagen content after stem cell therapy. The collagen content with Sircol ${ }^{\mathrm{TM}}$ method on zero day, $14^{\text {th }}$ day and 18th day were $11.98 \mu \mathrm{g} / \mathrm{mg}, 26.54 \mu \mathrm{g} / \mathrm{mg}$ and 29.24 $\mu \mathrm{g} / \mathrm{mg}$ which supports the findings of Ghani et al. [13] regarding wound healing. The tensile strength and 
Table-1. Constituents of the Conditioned media.

\begin{tabular}{lc}
\hline Constituents of media & Amount \\
\hline FBS (Fetal Bovine Serum) 10\%, Lonza & $5 \mathrm{ml}$ \\
Sodium Pyruvate 0.1\% Himedia & $0.5 \mathrm{ml}$ \\
NEA (Non essential amino acids) 0.1\%, Himedia & $0.5 \mathrm{ml}$ \\
DMEM (Dulbecco-modified Eagle medium) (MP pharmaceuticals & $18.5 \mathrm{ml}$ \\
Streptomycin (Sigma, Aldrich) & $0.5 \mathrm{ml}$ \\
L15 (Livosys 15) washing media & $25 \mathrm{ml}$ \\
Total & $50 \mathrm{ml}$ \\
\hline
\end{tabular}

Table-2. Biochemical parameters measured before and after implantation.

\begin{tabular}{lcc}
\hline Parameters & On the day of presentation & After $\mathbf{1 8}^{\text {th }}$ day of Healing \\
\hline Blood glucose $(\mathrm{mg} / \mathrm{dL})$ & 62.35 & 64.08 \\
Total Protein & 6.75 & 7.09 \\
Serum SGPT $(\mathrm{IU} / \mathrm{L})$ & 25.61 & 27.98 \\
Serum SGOT $(\mathrm{IU} / \mathrm{L})$ & 98.23 & 106.19 \\
SerumCholesterol $(\mathrm{mg} / \mathrm{dL})$ & 68.52 & 73.28 \\
Phosphorous $(\mathrm{mg} / \mathrm{dL})$ & 5.75 & 5.52 \\
Calcium $(\mathrm{mg} / \mathrm{dL})$ & 10.46 & 10.79 \\
\hline
\end{tabular}

elongation at break of normal skin and BM-MSCs treated skin were $20.23 \mathrm{MPa}, 13.95 \mathrm{MPa}$ and $104.85 \%, 35.79 \%$ respectively. While comparing the tensile stress and strain between normal skin and healed skin after BM-MSCs therapy, though normal skin shows higher value for breaking strength, the healed tissue was advancing towards proper stretchability and gaining the normal tensile strength. The wound assessment was studied for gross observation of wound viz types of exudates, extent of exudates, swelling and wound contraction. The wound healing was assessed by Bose et al. [14] in bovines on 0-3 scale, in horses by Gopinathan et al. [15] on 1-5 scale and in rats by Ramesh et al. [16].

In this case it was studied on 0-3 scale and found significant difference $(\mathrm{P} \leq 0.05)$ while comparing healing with that of zero day. The photographs of the wound were evaluated by three surgeons and showed complete healing on $18^{\text {th }}$ day (Fig.5). The result supports the findings of comparison of photographs by Borena et al. [7] and Sasaki et al. [17]. As per the study of Mc Farlin et al. [18] the BM MSCs accelerate the wound healing process in cutaneous wound in case of Sprague-Dawley rat. Supporting this Vojtassak et al. [19] reported the healing of a 25 year open wound in human being affected with diabetes within 4 weeks following BM-MSCs application. In this case after BM-MSCs application the 4 months chronic wound was healed within 18 days. The role of MSCs is attributed not only to their differentiation but also to their ability to produce various angiogenic factors including vascular endothelial growth factor (VEGF) and basic fibroblast growth factor (bFGF) [20]. The wound healing effects of skin is being mediated by the regenerative effects of transforming growth factor (TGF), fibroblast growth factor (FGF), fibronectinlike peptide, keratinocytes growth factor, epidermal growth factor and growth hormone releasing factor [21] and these factors might have been accelerated due to MSCs application. This result indicates that it may emerge as an effective therapeutic approach for chronic non-healing and ulcerative cutaneous wound in future. Therefore large scale randomised studies and clinical trials are needed to prove this promising option.

\section{Author's contribution}

JD and IN designed the study as this is a part of JD's $\mathrm{PhD}$ thesis and $\mathrm{IN}$ was his major advisor. PR helped in processing of BM. RKD analyzed the study during post therapy period. SSB helped during collection of BM and assisting throughout the study. All authors read and approved the final manuscript.

\section{Acknowledgements}

The authors are thankful to Cryobiology laboratory, Central Institute of Fresh Water Aquaculture (CIFA), Kausalyaganga, BBSR; Central Institute of plastics Engineering and Technology (CIPET), BBSR; Institute of Life Science (ILS), BBSR; RMRC (ICMR), BBSR; Dept of Veterinary Anatomy; Veterinary Pathology and Veterinary Biochemistry, Veterinary College, for providing facilities for this research work.

\section{References}

1 Slatter, D. (2003). Text book of small animal surgery. $3^{\text {rd }}$ edn. Pp. 250. Saunders, an imprint of Elsevier 
Science (USA).The Curlis Center Independence Square West Philadelphia, PA 19106.

2 Venugopalan, A. (2004). Essentials of Veterinary Surgery. Vijay Primlani for Oxford and IBH Publishing Co. Pvt. Ltd. Pp:105.

3 Fossum, T.W., Hedlund, C.S., Hulse, D.A., Johnson, A.L., Seim, H.B., Willard, M.D. and Carroll, G.L. (1997). Surgery of Integumentary System. In: Manual of Small Animal Surgery,2nd Edn. Mosby. pp. 132228.

4 Kim, S.W., Kim, H., Cho, H.J., Lee, J.U., Levit, R., et al. (2010). Human peripheral blood-derived CD31+ cells have robust angiogenic and vasculogenic properties and are effective for treating ischemic vascular disease, JAm Coll Cardiol, 56: 593-607.

5 Dash, N.R., Dash, S.N., Routray, P., Mohapatra, S., Mohapatra, P.C. (2009). Targeting Nonhealing Ulcers of Lower Extrimity in Human Through Autologous Bone Marrow-Derived Mesenchymal Stem Cells. Rejuvenation Research, Volume 12.pp: 359-365.

6 Diane, A., Harry, S., Fabien, F., Nancy, G., Francis, H., Viktor, M. and Michel, D. (2010). Multipotent mesenchymal stem cell grafting to treat cutaneous radiation syndrome: Development of a new mini pig model. Experimental Hematology.38: 945-956.

7 Borena, B.M., Pawde, A.M., Amarpal, Aithal, H.P., Kinjavdekar, P., Singh, R. and Kumar, D. (2009). Evaluation of healing potential of autologous bone marrow-derived nucleated cells on incisional wounds in dogs. Indian J. Vet. Surg. 30 (2): 85-89.

8 Graham, L.V.D., Sweetwyne, Pallero, M.A., MurphyUllrich, J. (2010). Intracellular Caireticulin Regulates Multiple Steps in fibrillar Collagen Expression, Traffing, and Processing into the Extracellular Matrix. The Journal of biological Chemistry vol. 285:7067-7078

9 Olaso, E., Hsin-Chieh, L., Wang, L. and Friedman, L. (2011). Impaired dermal wound healing in discoidin domain receptor 2- deficient mice associated with defective extracellular matrix remodeling. Fibrinogenesis and Tissue repair.1-9.

10 Ye, L.,Chen, L.,Yu, Q.,Cheng, F. (2010). Effect of recombinant human erythropoietin on the stemness of bone marrow derived mesenchymal stem cells in vito, Int J Stem cells, 3:175-182.

11 Chatterjee, S., Chaklader, M., Basak, P., Das, P., Das, M., Pereira, J. A., Dutta, R.K., Chaudhuri, S. and Law, S. (2010). An Animal Model of Chronic Aplastic Bone Marrow Faliure Following Pesticide Exposure in
Mice. International Journal of Stem Cells. Vol. 3. pp: 54-62.

12 Lee, K., Kim, A., Kim, M., Do, Y., Shin, S., Kim, J., Park, C., Kang, K., Kim, B., Joh, J., Oh, W., Hong, H. and Kim, D. (2008). Angiogenesis Induced by Autologous Whole Bone Marrow Stem Cells Transplantation. International Journal of Stem Cells.Vol-1:64-69.

13 Ghani, A., Pandey, S.K. and Kolte, G.N. (1981). Histological and histochemical evaluation of certain local medicaments as accelerator of wound healing. Indian J. of Indig. Suppl. 1 (2): 37-43.

14 Bose, V.S.C., Pattnaik, T.K., Bisoi, P.C. and Mohapatra, H.K. (2006). Evaluation of Skin Heal spray for wound healing in domestic animals. Livestock international.11-16.

15 Gopinathan, A., Pawade, A.M., Singh, K., Amarpal, P., Kinjavdekar, H.P., Aithal and G R Singh. (2007). Evaluation of calendula-glycerine for healing of chronic wounds in horses. IJVS 28(2):130-132.

16 Ramesh, H.A., Mohammed, A., Malay, B. and Mohammed, A. (2010). Research Journal of Pharmaceuticals, Biological and Chemical Sciences, July-Sept. RJPBCS Volume 1 Issue-3, Page no. 750.

17 Sasaki, M., Abe, R., Fujita, Y., Ando, S., Inokuma, D. and Shimizu, H. (2008). Mesenchymal Stem Cells are Recruited into Wounded Skin and Contribute to Wound Repair by Trans-differentiation into Multiple Skin Cell Type. The Journal of Immunology. pp. 2581-2587.

18 McFarlin, K., Gao. X., Liu, y., Dulchavsky, D.S., Kwon, D., Arbab, A.S., Bansal, Moo Li, Y., Chopp, M., Dulchavsky, S.A. and Gautam, S.C. (2006). Bone marrow-derived mesenchymal stromal cells accelerate wound healing in the rats. Wound Rep. Reg. 14: 471-478.

19 Vojtassak, J., Danisovic, L., Kubes, M., Bakos, D., Jarabek, L. (2006). Autobiograft and mesenchymal stem cells in treatment of diabetic foot. Neur Endocrinol Lett. 27: 134-137.

20 Al- Khalidi, A., Eliopoulos, N, Martineau, D, Lejeune, L, Lachapelle, K, Galipeau, J. (2003). Postnatal bone marrow stromal cells elicit a potent VEGF-dependent neoangiogenic response in vivo. Gene Ther, 10:621-629.

21 Wu, C.H., Chang, G.Y., Chang, W.C., Hsu, C.T., Che, R.S. (2003). Wound healing effects of porcine placental extracts on rats with thermal injury. $\mathrm{Br} J$ Dermatol, 148 (2): 236-45. 